\section{Inhibitory Effect of Salivary Fluids on PCR: Potency and Removal}

\author{
A.S. Ochert, ${ }^{1,3}$ \\ A.W. Boulter, ${ }^{1,3}$ \\ W. Birnbaum, \\ N.W. Johnson, \\ and C.G. Teo $^{3}$
}

${ }^{1}$ Royal College of Surgeons Department of Dental Sciences and ${ }^{2}$ Department of

Primary Dental Care, King's College

School of Medicine and Dentistry;

${ }^{3}$ Virus Reference Division, Central

Public Health Laboratory, Public Health Laboratory Service, London, UK
Various body fluids contain agents that inhibit the PCR. Such fluids include urine, ${ }^{(1,2)}$ serum, $^{(3-5)}$ feces, $^{(6,7)}$ amniotic fluid, ${ }^{(8)}$ and cerebrospinal fluid. ${ }^{(8)}$ When detection or quantification of microbial genomes from clinical specimens is desired, the presence of PCR inhibitory factors potentially leads to false-negative results or underestimations, respectively.

We have been engaged in PCR detection and quantification of the EpsteinBarr virus (EBV) genome in oral fluids. Preliminary attempts to demonstrate viral DNA in whole mouth fluid (WMF) and parotid saliva (PS) from study subjects resulted in poor positivity yields. This was despite having established PCR conditions for the sensitive detection of EBV derived from cell culture and of plasmids that contain subgenomic EBV inserts. These results were surprising in view of previous reports that the virus could be isolated from saliva at high rates by the lymphocyte transformation assay. ${ }^{(9,10)}$ We therefore investigated the possibility that saliva might also contain PCR inhibitory factors. We demonstrate here that saliva potently inhibits PCR and describe a simple procedure to eliminate this effect.

\section{MATERIALS AND METHODS}

WMF was collected from 10 healthy human subjects after mechanical stimulation by the chewing of sterile rubber bands. PS was obtained by applying a Lashley cup to Stensens' duct; stimulation was achieved by placing citric acid crystals on the tongue at $\sim 30$-sec intervals. WMF collection preceded PS collection. WMF was clarified, passed through $5.0-\mu \mathrm{m}$ Acrodisc filters, aliquoted, and stored at $-70^{\circ} \mathrm{C}$ until use. PS samples were passed through $0.45-\mu \mathrm{m}$ filters, similiarly aliquoted, and frozen.

Plasmid pBR322 containing the nonreiterated Bam $\mathrm{HI} \mathrm{K}$ fragment of the B95-8 strain of $\mathrm{EBV}^{(11)}$ was used as the principal source of DNA template for PCR. Oligonucleotide PCR primers and probe used, respectively, for the amplification and detection of the BamHI K region of EBV were synthesized in an Applied Biosystems 380B synthesizer; the sequences of these oligomers have been reported previously. ${ }^{(12)}$ PCR was performed in a Perkin-Elmer Cetus PCR DNA thermal cycler. Thirty-five cycles were performed per run. Cycling conditions were as follows: denaturation at $94^{\circ} \mathrm{C}$ for $1 \mathrm{~min}$; annealing at $50^{\circ} \mathrm{C}$ for 40 sec; and extension at $72^{\circ} \mathrm{C}$ for $1 \mathrm{~min}$.

WMF and PS samples, individually spiked with plasmid DNA, underwent each of the following DNA extraction procedures: Geneclean II (Stratech Scientific, Luton, UK); Magic DNA Clean-up System (Promega, Madison, WI); Sephadex G-50 chromatography; phenol-chloroform; guanidinium thiocycanate/silica with or without proteinase $\mathrm{K}$ pretreatment; microwaving; boiling for $5 \mathrm{~min}$; and Chelex-100. The Geneclean and Magiprep methods were performed according to manufacturers' instructions. G-50 chromatography was performed as described by de Franchis et al. ${ }^{(13)}$ Extraction with phenol-chloroform was performed as follows: Each 100- $\mu$ l WMF or PS sample was vortexed with an equal volume of 25:24:1 phenol/chloroform/ isoamyl alcohol and spun briefly; the process was repeated following recovery of the aqueous phase. This was then vortexed with an equal volume of $24: 1$ chloroform/isoamyl alcohol, spun, aspirated, and precipitated with $3 \mathrm{~m}$ sodium acetate ( $\mathrm{pH}$ 5.2) and ethanol. The precipitate was washed in $70 \%$ ethanol, air-dried, and suspended in $20 \mu \mathrm{l}$ of ultrapure water. The guanidinium thiocyanate/silica extraction method essentially followed that of Boom et al. ${ }^{(14)}$ Where treatment with SDS and proteinase $K$ was required prior to extraction, a later modification of the Boom protocol ${ }^{(15)}$ was followed. Microwaving $^{(16)}$ was performed as follows: $0.5-\mathrm{ml}$ polypropylene tubes each containing $100 \mu \mathrm{l}$ of sample were radially arranged around the center of the glass dish of a Toshiba ER-7820 microwave oven with lids facing outward; tubes were heated on full power for 2 min. To extract DNA using the Chelex$100,100 \mu \mathrm{l}$ of sample in a $500-\mu \mathrm{l}$ microcentrifuge tube was mixed with $20 \mu \mathrm{l}$ of $25 \%$ (wt/vol) Chelex-100 (Bio-Rad Laboratories, Richmond, $\mathrm{CA}$ ) in sterile water, vortexed, incubated at $56^{\circ} \mathrm{C}$ for $30 \mathrm{~min}$, vortexed, heated at $95^{\circ} \mathrm{C}$ for $3 \mathrm{~min}$, vortexed, spun in a microcentrifuge for 3 $\mathrm{min}$, and the supernate aspirated for PCR.

Each PCR mixture consisted of $30 \mu \mathrm{l}$ of extracted DNA, 20 pmoles of each primer pair, 0.3 units of Taq polymerase (Bioline, London, UK), and $0.4 \mathrm{~nm}$ dNTPS in a mixture consisting of $50 \mathrm{~mm}$ $\mathrm{KCl}, 1 \mathrm{~mm} \mathrm{MgCl}_{2}, 10 \mathrm{~mm}$ Tris- $\mathrm{HCl}(\mathrm{pH}$ $8.5), 0.01 \%(\mathrm{wt} / \mathrm{vol})$ gelatin, $0.5 \%$ Tween 20 , and $0.1 \%$ Triton $X-100$ in a total vol- 


\section{Technical TipslIIII $\square$}

ume of $50 \mu$ l. After amplification, products were submitted to agarose gel electrophoresis, stained with ethidium bromide, and visualized by UV illumination.

\section{RESULTS}

Thirty microliters of WMF samples from 10 subjects each containing $3 \times 10^{5}$ copies of plasmid were subjected to PCR. The following extraction protocols were uniformly unsuccessful in reversing the PCR inhibitory effect: Geneclean, Magic, Sephadex G-50 chromatography, and phenol-chloroform. Microwaving and boiling were more successful in reversing the inhibition in WMF, as most samples yielded positive results after treat- ment with either method (Fig. 1, top). A further study of one WMF sample showed that prolonged boiling of WMF totally removed the inhibition (Fig. 2), as could extended microwaving (data not shown). The guanidinium thiocyanate procedure was less successful than the heating methods (Fig. 1, bottom). Proteinase K pretreatment before guanidinium extraction did not improve upon the outcome (not shown). In contrast, treatment of WMF samples with Chelex100 resulted in positive reactions in all samples (Fig. 1, bottom).

Thirty microliters of PS samples was similarly mixed with $3 \times 10^{5}$ copies of template DNA. Procedures that were successful in removing inhibitors in WMF, including heat-treatment methods (boil- ing for $5 \mathrm{~min}$ and microwaving for 2 min), failed to result in amplification of template in PS (data not shown). Furthermore, prolonged boiling was not able to overcome inhibition (Fig. 2). Extraction of PS samples with Chelex-100 did not lead to positive PCR reactions, even though the PCR procedure itself could demonstrably amplify from 10 to 100 copies of template DNA (Fig. 3). Hence, PS exhibited an inhibitory effect that was more resistant than WMF to removal.

Inhibition in PS could nonetheless be overcome. Repeated extractions with Chelex-100 improved the yields, and four sequential extractions totally removed inhibition (data not shown). Quenching of inhibition was also
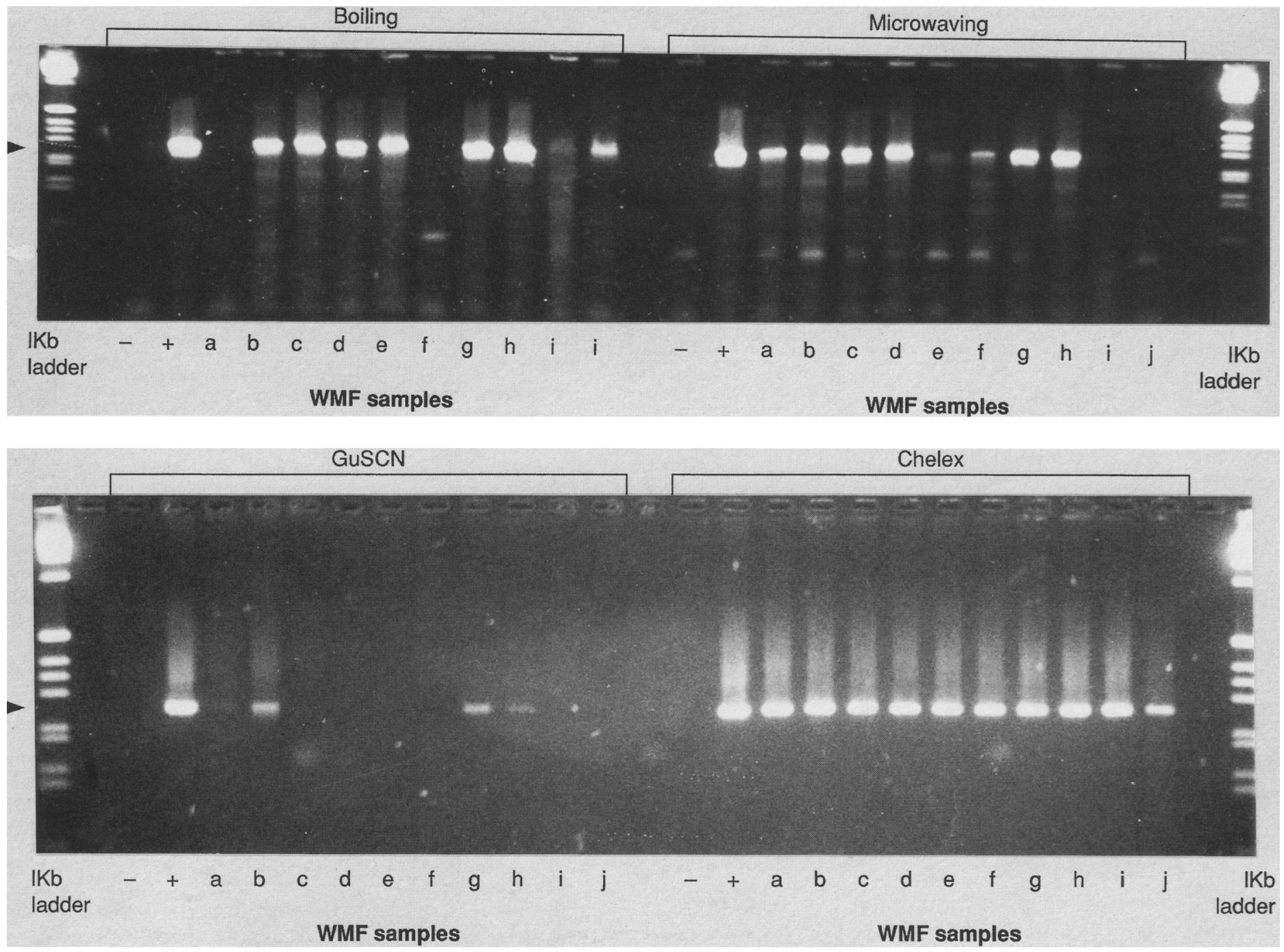

FIGURE 1 Comparison of methods to reduce PCR inhibition in WMF samples. Ten samples, designated $a-j$, each containing $10^{7}$ copies/ml of the EBV BamHI K insert in pBR322, were subjected to four separate procedures as indicated. (GuSCN) Guanidinium thiocyanate. (+) Positive plasmid control; (-) negative water control. Amplicons hybridize to an oligonucleotide probe specific to the PCR template (data not shown). Arrowheads indicate the expected banding position of the amplified product in relation to molecular weight markers. 


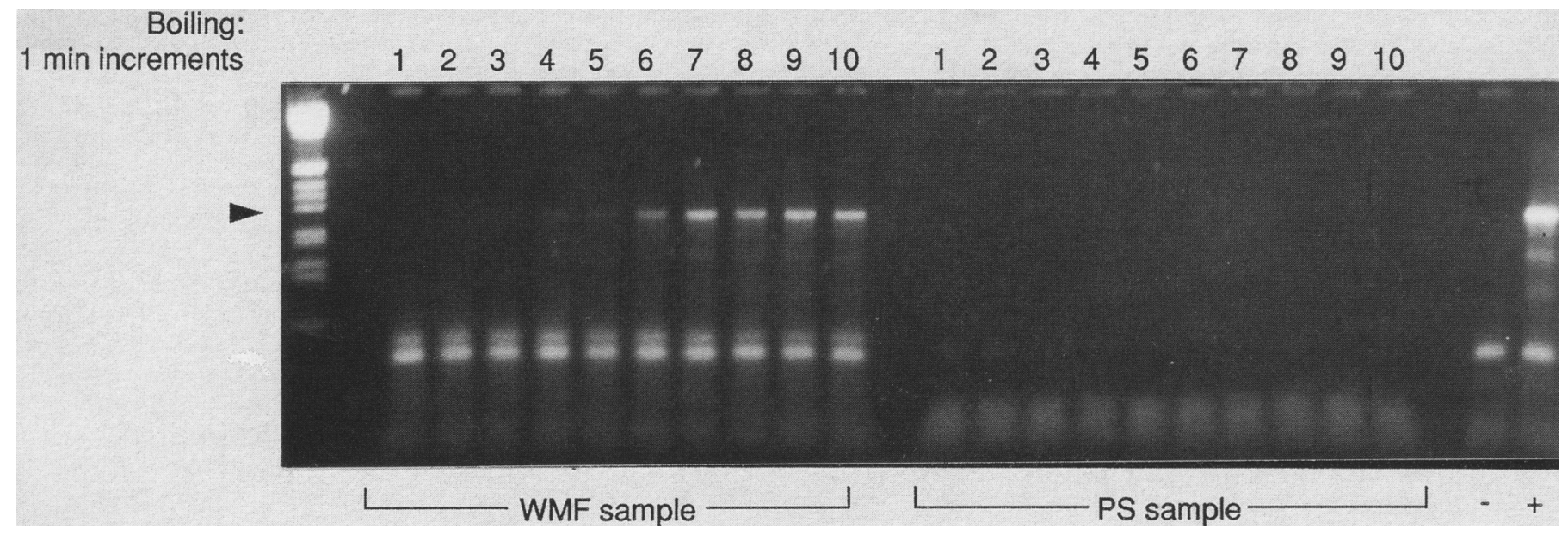

FIGURE 2 Effect of prolonged boiling on the removal of PCR inhibition in WMF and PS of a single individual. Durations of boiling are as indicated. ,,+- and arrowhead bear the same significance as in Fig. 1.

achieved with a single extraction using four times the quantity of Chelex employed previously in sequential extractions (data not shown).

\section{DISCUSSION}

Previous studies on the PCR detection of microbial genomes in saliva ${ }^{(17-23)}$ have generally not validated detection data against those produced by other detection methods that were of equivalent sensitivity. The inhibitory property of saliva could not therefore be suspected or revealed. One study did evaluate the performance of PCR against virus isolation for the detection of cytomegalovirus in saliva, ${ }^{(24)}$ and it reported that a proportion of samples was PCR negative but isolation positive; this discordance was attributed to the possible presence of interfering substances in the saliva. In this study we provide evidence that $\mathrm{WMF}$ and, in particular, PS exert a potent inhibitory effect on PCR. Inhibition in these body fluids could be demonstrated even when they contained $10^{7}$ copies $/ \mathrm{ml}$ of template DNA.

The inhibitory factors are probably constituents of salivary gland secretions. The lesser degree of inhibition in WMF compared with PS (Fig. 2) is probably the result of dilution by other oral secretions, for example, crevicular fluid or pharyngeal secretions.
The chemical nature of the inhibitors remains to be characterized. By inference, they are unlikely to be proteins, because of their relative heat resistance and the observation that extraction procedures based on phenol-chloroform or proteinase $\mathrm{K}$ did not prevent inhibition. The persistence of inhibition after processing with gel matrices or ion-exchange resins suggests that low-molecular-weight ionic moieties are also not inhibitors. Polysaccharides are possible candidates. In this regard, the known activity of Chelex-100 in reversing the PCR inhibitory effect of heparin, ${ }^{(25)}$ an anionic polysaccharide, is of interest.

This study shows that PCR inhibition by WMF can be consistently quenched

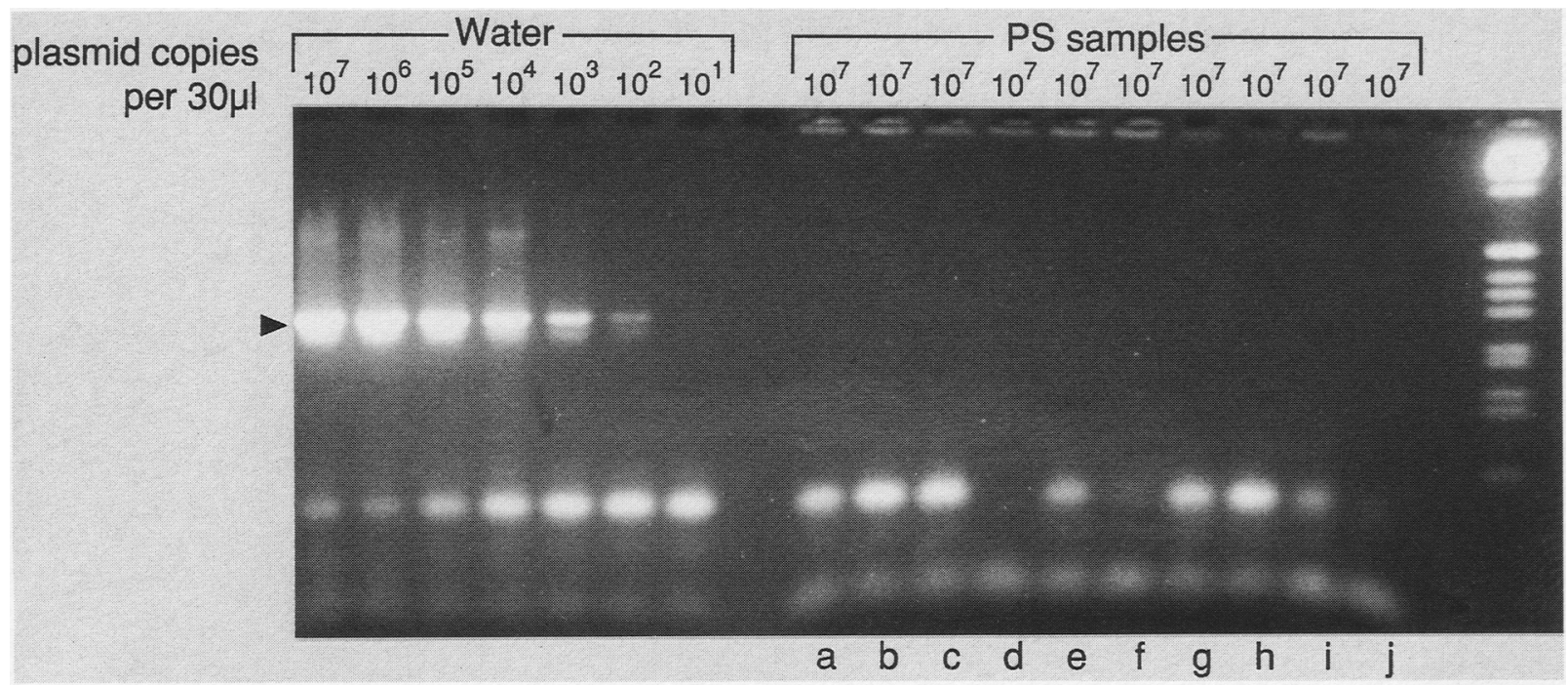

FIGURE 3 Potency of inhibition in PS samples. (Left) Amplification of 10-fold dilutions of template DNA in water. (Right) Amplification of PS samples from 10 individuals $(a-j)$, each containing $10^{7}$ copies $/ \mathrm{ml}$ of template DNA after extraction with Chelex-100. 
by prolonged heating and by Chelex-100 extraction, whereas the inhibitory effect in PS can only be removed by Chelex treatment. The choice of a procedure applicable to both WMF and PS is therefore reduced to one based on Chelex-100, but it has to take into account the requirement for PS samples to be sequentially extracted or loaded with a greater quantity of Chelex-100. It is proposed that to each $100 \mu \mathrm{l}$ of WMF or PS sample, $25 \%$ (wt/vol) Chelex-100 is added at a volume of 20 or $80 \mu \mathrm{l}$, respectively; subsequent steps are then performed as detailed previously (see above). This procedure, moreover, reduces the risk of cross-contamination in two ways: It curtails the generation of aerosols (as may occur following intense heating) and limits the number of handling and pipetting steps (as would be required in other extraction protocols).

\section{REFERENCES}

1. Khan, G., H.O. Kangro, P.J. Coates, and R.B. Heath. 1991. Inhibitory effects of urine on the polymerase chain reaction for cytomegalovirus DNA. J. Clin. Pathol. 44: 360-365.

2. Buffone, G.J., G.J. Demmler, C.M. Schimbor, and J. Green. 1991. Improved amplification of cytomegalovirus DNA from urine after purification of DNA with glass beads. Clin. Chem. 37: 1945-1949.

3. Clewley, J.P. 1989. Polymerase chain reaction assay of parvovirus B19 DNA in clinical specimens. J. Clin. Microbiol. 27: 2647-2651.

4. Zeldis, J.B., J.H. Lee, D. Mamish, D.J. Finegold, R. Sircar, Q. Ling, P.J. Knudsen, I.K. Kuramoto, and L.T. Mimms. 1989. Direct method for detecting small quantities of hepatitis B virus DNA in serum and plasma using the polymerase chain reaction. J. Clin. Invest. 84: 1503-1508.

5. Frickhofen, N. and N.S. Young. 1991. A rapid method of sample preparation for detection of DNA viruses in human serum by polymerase chain reaction. J. Virol. Methods 35: 65-72.

6. Wilde, J., J. Eiden, and R. Yolken. 1990. Removal of inhibitory substances from human fecal specimens for detection of group A rotaviruses by reverse transcriptase and polymerase chain reactions. J. Clin. Microbiol. 28: 1300-1307.

7. Jiang, X., J. Wang, D.Y. Graham, and M.K. Estes. 1992. Detection of Norwalk virus in stool by polymerase chain reaction. $J$. Clin. Microbiol. 30: 2529-2534.

8. Gimprel, E., P.J. Sanchez, G.D. Wendel, J.M. Burstain, G.H. McCracken, J.D. Radolf, and M.V. Norgard. 1991. Use of poly- merase chain reaction and rabbit infectivity testing to detect Treponema pallidum in amniotic fluid, fetal and noenatal sera, and cerebrospinal fluid. J. Clin. Microbiol. 29: 1711-1718.

9. Niederman, J.C., G. Miller, H.A. Pearson, J.S. Pagano, and J.M. Dowaliby. 1976. Infectious mononucleosis: Epstein-Barr virus shedding in saliva and the oropharynx. N. Engl. J. Med. 294: 1355-1359.

10. Morgan, D.G., J.C. Niederman, G. Miller, H.W. Smith, and J.M. Dowaliby. 1979. Site of Epstein-Barr virus replication in the orpharynx. Lancet ii: 1154-1157.

11. Given, D. and E. Kieff. 1978. DNA of Epstein-Barr virus. IV. Linkage map for restriction enzyme fragments of the B95-8 and W91 strains of EBV. J. Virol. 28: 524542.

12. Crouse, C.A., S.C. Pflugfelder, T. Cleary. S.M. Derrick, and S. Atherton. 1990. Detection of Epstein-Barr virus genomes in normal human lacrimal glands. J. Clin. Microbiol. 28: 1026-1032.

13. de Franchis R., N.C.P. Cross, N.S. Foulkes, and T.M. Cox. 1988. A potent inhibitor of Taq polymerase copurifies with human genomic DNA. Nucleic Acids Res. 16: 10355 .

14. Boom, R., C.J. Sol, M.M. Salimans, C.L. Jansen., P.M. Wertheim-van Dillen, and J. van der Noordaa. 1990. Rapid and simple method for purification of nucleic acids. J. Clin. Microbiol. 28: 495-503.

15. Boom, R., C.J. Sol, R. Heijtink, P.M. Wertheim-van Dillen, and J. van der Noordaa. 1991. Rapid purification of hepatitis B virus DNA. I. Clin. Microbiol. 29: 1804 1811.

16. Cheyrou A., C. Guyomarch, P. Jasserand, and P. Blouin. 1991. Improved detection of HBV DNA by PCR after microwave treatment of serum. Nucleic Acids Res. 19: 4006.

17. Jarrett, R.F., D.A. Clark, S.F. Josephs, and D.E. Onions. 1990. Detection of human herpesvirus-6 DNA in peripheral blood and saliva. J. Med. Virol. 32: 73-76.

18. Greenfield, C., V. Sinickas, and L.C. Harrison. 1991. Detection of cytomegalovirus by the polymerase chain reaction. A simple, rapid and sensitive non-radioactive method. Med. J. Aust. 154: 383-385.

19. Goto Y., C.K. Yeh, A.L. Notkins, and B.S. Prabhakar. 1991. Detection of proviral sequences in saliva of patients infected with human immunodeficiency virus type 1 . AIDS Res. Hum. Retrovir. 7: 343-347.

20. Liou, T.-C., T.-T. Chang, K.-C. X.-Z, Young, C.-Y. Lin, and H.-L. Wu. 1992. Detection of HCV RNA in saliva, urine, seminal fluid and ascites. $J$. Med. Virol. 37: 197-202.

21. Saito, I., S. Nishimura, I. Kudo, R.I. Fox, and I. Moro. 1991. Detection of EpsteinBarr virus and human herpes virus type 6 in saliva from patients with lymphopro- liferative diseases by the polymerase chain reaction. Arch. Oral Biol. 36: 779_ 784.

22. Wang, J.T., T.H. Wang, J.C. Sheu, J.T. Lin, and D.S. Chen. 1992. Hepatitis C virus RNA in saliva of patients with posttransfusion hepatitis and low efficiency of transmission among spouses. J. Med. $\mathrm{Vi}$ rol. 36: 28-31.

23. Cone R.W., M.-L.W. Huang, R. Ashley, and L. Corey. 1993. Human herpesvirus 6 DNA in peripheral blood cells and saliva from immunocompetent individuals. $J$. Clin. Microbiol. 31: 1262-1267.

24. Warren, W.P., K. Balcarek, R. Smith, and R.F. Pass. 1992. Comparison of rapid methods of detection of cytomegalovirus in saliva with virus isolation in tissue culture. J. Clin. Microbiol. 30: 786-789.

25. Poli, F., R, Cattaneo, L. Crespiatico, A. Nocco, and G. Sirchia. 1993. A rapid, simple method for reversing the inhibitory effect of heparin on PCR for HLA class II typing. PCR Methods Applic. 2: 356-358.

Received October 28, 1993; accepted in revised form March 7, 1994. 


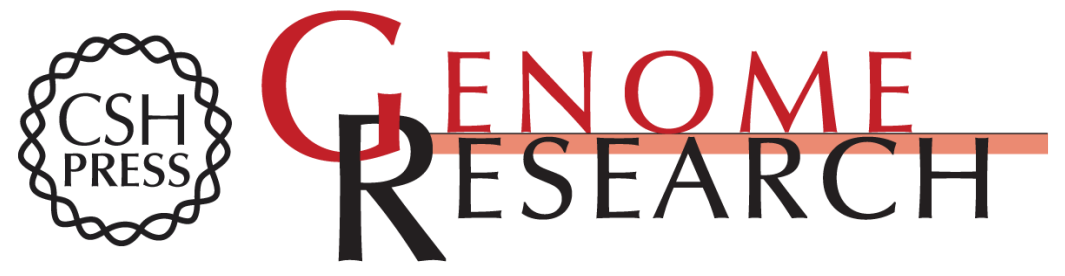

\section{Inhibitory effect of salivary fluids on PCR: potency and removal.}

A S Ochert, A W Boulter, W Birnbaum, et al.

Genome Res. 1994 3: 365-368

References This article cites 24 articles, 12 of which can be accessed free at:

http://genome.cshlp.org/content/3/6/365.full.html\#ref-list-1

\section{License}

Email Alerting Receive free email alerts when new articles cite this article - sign up in the box at the Service top right corner of the article or click here.

\section{Affordable, Accurate Sequencing.}

To subscribe to Genome Research go to: https://genome.cshlp.org/subscriptions 